\title{
An Initial Investigation on the Distribution, Living Conditions and Traits of the Hazel in Great Xing'an Ridge Region
}

\author{
Qian Wang $^{1 \#}$, Shuchai Su${ }^{1 *}$, Wanping Liu ${ }^{1}$, Dejie Yin ${ }^{1}$, Zhongqiu Tang ${ }^{2}$, Di Xu ${ }^{2}$ \\ ${ }^{1}$ Key Laboratory for Silviculture and Conservation, Ministry of Education, Beijing Forestry University, Beijing, China; ${ }^{2}$ Agricultural \\ and Forestry Research Institute of Great Xing'an Ridge, Jiagedaqi, China.

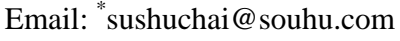

Received August $6^{\text {th }}, 2011$; revised August 20 ${ }^{\text {th }}, 2011$; accepted September $5^{\text {th }}, 2011$.

\begin{abstract}
To take full advantage of the natural hazel resources and improve its yield and quality in Great Xing'an Ridge region, we carried out an initial investigation. The result showed that: there are two species in this area: Corylus heterophlla and Corylus mandshurica. They mainly distribute from south of Xinlin town, Huma county, Heilongjiang province to south boundary of Great Xing'an Ridge in mountain and hilly areas. Most of hazel in this area was under the state of natural growth with no scientific man-management. Soil where Corylus heterophlla grew was about $40 \mathrm{~cm}$ to $50 \mathrm{~cm}$ and Corylus mandshurica was $30 \mathrm{~cm}$ to $45 \mathrm{~cm}$. The main plant disease was powdery mildew and insect pest were Curculio dieckmani, Zeuzera sp. and Faust Cockchafer. 100-seed weight of Corylus heterophylla was more than twice of Corylus mandshuria. However, Corylus mandshuria was plumper, had much more kernel and much less empty shell than Corylus heterophylla, and what's more, shell sickness of it turned to be significantly thinner than Corylus heterophylla, all of which showed great cultivation value and economic commodity value.
\end{abstract}

Keywords: Corylus Heterophylla, Corylus Mandshurica, Distribution, Quality, Condition

\section{Introduction}

Hazel which originated in China and rich in fat, protein, carbohydrates, together with many kinds of vitamins and minerals is a kind of precious woody grain and oil resources, containing a high economic value. According to the analysis, hazel contains $57.5 \%-69.8 \%$ fat, $14.1 \%$ $18.0 \%$ protein, $6.5 \%$ - 9.3\% carbohydrate, only $4.1 \%$ $5.8 \%$ water and a variety of vitamins (Vc, Ve, $\mathrm{Vb}$ ) and minerals (Ca, K, P, Fe etc.) [1]. What is more, unsaturated fatty acid content reaches up to $90 \%$ in hazel oil, far higher than conventional vegetable oils. Among the oil oleic acid is the most $(74.1 \%-82.1 \%)$ and linoleum acid come to the second (12.7\%). It contains much less

"Wang Qian, Master in Beijing Forestry University.

E-mail: 1837857779@qq.com, address: 990Mailbox, No. 35 Qinghua East Road, Beijing 100083, China.

*Corresponding Author Introduction: Su Shuchai, professor. Research: Pomology.

E-mail: sushuchai@sohu.com, address: 100083, Beijing No. 35 Qinghua East Road, Beijing Forestry University.

This study was supported by State Forestry Administration Key Project "Study on key technology about Hazelnut Breeding and Cultivation" (2011-03). iodine and is clear orange with mellow taste, so turns out to be a high quality oil [2]. Hazel is one of the world's four nuts and is well received by consumers due to its rich nutritious and unique flavor. Hazelnut oil can soften blood vessel, which could help the elderly prevent cardiovascular disease and promote longevity [3]. Distribution of hazel root is deep and wide, which could reach $1.5 \mathrm{~m}$ deep and 1 - $2 \mathrm{~m}$ wide respectively. Meanwhile, they are easy to form continuous hazel forest because their roots could stretch in the surface soil and sprout tillers [4]. As a result, it becomes very helpful for soil, water conservation and for woodland soil improvement due to its well-developed root system.

Hazel belongs to Corylaceae, Corylus $L$. in plant taxonomy and there are about 20 species around the world. They mainly distribute in the Northern Hemisphere from Cold Temperature Zone to Subtropical Climate Zone [5]. 10 of the 20 species originated in China and scattered in 22 provinces (regions), among which Corylus heterophlla, C. mandshurica, C. kweichowensis Hu, C. chinensis Franch, C. fargesii Schneid, C. yunnanensis A. Camus, C. ferox Wall, C. wangii Hu were 8 original species 
and Corylus heterophlla $\times$ corylus avellana and C. avellana L. are 2 cultivars [6].

Corylus heterophlla and Corylus mandshurica are two species containing high economic value in the north of China. Corylus heterophlla, a small deciduous tree or shrub and alias hazel or hazelnut, mainly distribute in mountains or hilly regions at an altitude of $200-800 \mathrm{~m}$. It is divided into 7 types according to different shapes, and they respectively are round hazel, cone hazel, oblate hazel, long round hazel, flat hazel, sharp hazel and flattopped hazel [7]. Corylus mandshuria, alias fire hazel or Corylus mandshuria maxim, is a $2-4 \mathrm{~m}$ tall shrub. They distribute in forest or mountains in Temperate Zone or Warm Temperate Zone, and often grow among birch, aspen, Mongolian oak, oak or on the edge of other summer green broad-leaved forest.

Hazel is a major nut tree in China. It distributes in Heilongjiang, Jilin, Liaoning, Inner Mongolia, Hebei, Shaanxi and Shanxi province. In China, this ancient fruit tree is always in the original wild state and research on it has not begun until the 1970s. After thirty years research, hazelnut was finally included within cultivation fruit tree. Consequently, Hazel, the new fruit tree who has long been known but with so short history of artificial cultivation has attracted more and more attention with the implementation of the conversion of cropland to forest program and development of economic forest industry [8].

Nowadays, the current development and utilization and other aspects of the research of hazel focused on the biology and ecology in China from the economic forest's development status. As oleiferous tree species, hazelnut could bring tremendous economic and ecological benefits through scientific management, and meanwhile promote local economic development together with people's income increase.

Because hazel has always been in the original wild state in China, it led to smaller nuts, low kernel rate and poor commodity traits. What's more, serious insect fruit result in yield and quality significantly decreased. In recent years, not only no hazel was exported from China, but a large number of large fruit-European hazelnut was imported as hazelnut decline in the quality in China, which has a serious impact on our hazel industry [9]. In summary, detailed investigation and scientific management on wild hazel resource in China is imminent.

Most of hazel in Great Xing'an Ridge region is similarly under pure wild growth at this stage with no scientific artificial management. In addition, development of hazel product in this area is still in primitive stage and the major sales are primary original products. Given the status of local hazelnut resources, we conducted this preliminary investigation and study in order to make full use of this wild hazel, to improve its yield and quality. And the last purpose of the present study is to provide a theoretical basis for rational exploitation and utilization.

\section{Materials and Methods}

\subsection{Sampling Site and Background}

Great Xing'an Ridge is an important mountain in the northeast of China and it stretches from $43^{\circ}-53^{\circ} 30^{\prime} \mathrm{N}$ latitude to $117^{\circ} 20^{\prime}-126^{\circ} \mathrm{E}$ longitude. Altitude of mountains range from 600 - 1000 meters, and some peaks are close to 1400 meters. This area has large temperature difference between day and night. The annual average temperature is $-1.2^{\circ} \mathrm{C}-5^{\circ} \mathrm{C}$, and the lowest temperature is $-52.3^{\circ} \mathrm{C}$. July average temperatures is $16^{\circ} \mathrm{C}-20^{\circ} \mathrm{C}$. The annual accumulated temperature reaches $1100^{\circ} \mathrm{C}$ $1700^{\circ} \mathrm{C}$. Its frost-free period is about $90-110$ days, and average annual precipitation achieves $400-600 \mathrm{~mm}$. What is more, Great Xing'an Ridge is covered with vast expanse of forest. Its forest area is 6,463,600 hectares, and forest coverage rate reaches up to $75.16 \%$.

Great Xing'an Ridge in northeast of China own the richest hazel resource. The area of hazel in Great Xing' an Ridge came up to $670,000 \mathrm{hm}^{2}$ [10]. They mainly distribute in sunny, fertile, deep, well drained mountain soil in southeast of Great Xing'an Ridge. The hazel here is often contiguous and focused and large hazel forest range from one hectare to hundreds hectare. Hazel shrubs can be divided into shrub layer and herb layer, and the cover degree of shrub layer could come up to $78 \%$ - 80\% which composed mainly by hazel with $80000-150,000$ hazel trees per hectare in average [11]. Although there were so much hazel resource in Great Xing'an Ridge, they had always been in the state of natural wild growth and had never really got exploration.

For a long time, production structure of forest area was single and exploration, utilization and protection of hazel had not been paid enough attention. Consequently, greens nuts were always picked by local people in every harvest reason with deforestation, thus, resulting in nut yield and quality declining and increasing proportion of empty seeds, shriveled kernels and serious insect nuts.

So, we randomly chose several sampling sites for survey orderly from Jiagedaqi County, Nenjiang County and Huma County to make an initial investigation and research to provide a theoretical basis for rational exploitation and utilization.

The following considerations were used to select sampling sites: 1) the area should be wide and easily identifiable in GIS images, and 2) the area should not be destroyed by farmland or highways and could represent the local hazel growth conditions. Therefore, based on the aforementioned considerations a total of 11 samples were collected in the present study, at each sampling site, ha- 
zel was collected from a $2.5 \mathrm{~m} \times 2.5 \mathrm{~m}$ area. The geo graphic coordinates of sampling site are listed in Table 1 and locations of the study area are showed in Figure 1.

\subsection{Test Method}

Check out the hazel forest location by GPS and note their detailed latitude, longitude, altitude and record the habitat of the hazel forest according to actual situation.

Note the plant diseases and pests on leaves, branches and shoots of the hazel forest on experimental points. Compare the types and severity of diseases, pests and check out which is the most harmful.

Excavate the soil where hazel forest grow and record the thickness of it.

Have a preliminary understanding of hazel in this area by investigating the hazel forest, local markets, and information provided by experts in local forestry bureau. 10 robust Corylus heterophylla trees with no plant diseases or insect pest together with 10 Corylus mandshuria trees were selected for the experiment. Nuts of the two

Table1. Geographic coordinates of sampling site.

\begin{tabular}{ccc}
\hline & \multicolumn{2}{c}{ Geographic coordinates } \\
\cline { 2 - 3 } Samling site & North latitude & East longitude \\
\hline 1 & $51^{\circ} 21^{\prime} 32^{\prime \prime}$ & $124^{\circ} 28^{\prime} 14^{\prime \prime}$ \\
2 & $50^{\circ} 20^{\prime} 23^{\prime \prime}$ & $124^{\circ} 41^{\prime} 43^{\prime \prime}$ \\
3 & $50^{\circ} 33^{\prime} 42^{\prime \prime}$ & $125^{\circ} 75^{\prime} 41^{\prime \prime}$ \\
4 & $50^{\circ} 33^{\prime} 21^{\prime \prime}$ & $125^{\circ} 22^{\prime} 12^{\prime \prime}$ \\
5 & $50^{\circ} 37^{\prime} 09^{\prime \prime}$ & $125^{\circ} 53^{\prime} 24^{\prime \prime}$ \\
6 & $50^{\circ} 56^{\prime} 20^{\prime \prime}$ & $126^{\circ} 04^{\prime} 43^{\prime \prime}$ \\
7 & $51^{\circ} 04^{\prime} 30^{\prime \prime}$ & $126^{\circ} 17^{\prime} 54^{\prime \prime}$ \\
8 & $51^{\circ} 09^{\prime} 03^{\prime \prime}$ & $126^{\circ} 35^{\prime} 53^{\prime \prime}$ \\
9 & $51^{\circ} 09^{\prime} 02^{\prime \prime}$ & $126^{\circ} 08^{\prime} 14^{\prime \prime}$ \\
10 & $51^{\circ} 20^{\prime} 17^{\prime \prime}$ & $124^{\circ} 06^{\prime} 12^{\prime \prime}$ \\
11 & $50^{\circ} 17^{\prime} 52^{\prime \prime}$ & $124^{\circ} 07^{\prime} 20^{\prime \prime}$ \\
\hline
\end{tabular}

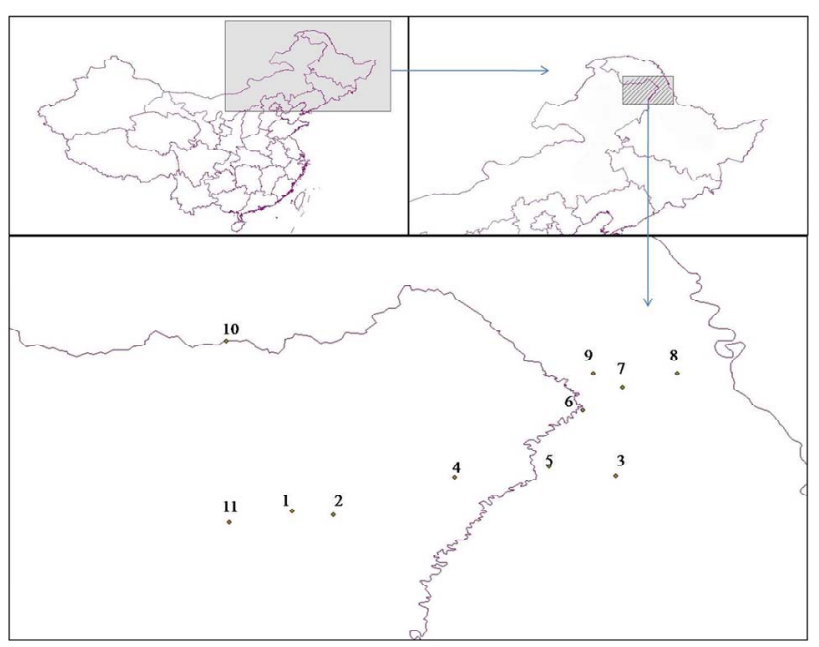

Figure 1. Location of the study area. ${ }^{a}$ : In the image sampling sites are represented by points. species were selectively picked and brought to the laboratory for air dry. 90 Corylus heterophylla nuts and 90 Corylus mandshuria nuts were randomly selected for the test and each 30 nuts as duplication 30 days later.

The weight of nuts were weight by $1 / 10,000$ electronic balance, and fruit size, shell thickness and other related economic indicators were measured by vernier caliper.

The indicators are as follows: traverse diameter $\left(\mathrm{x}_{1}\right)$, longitudinal diameter $\left(\mathrm{x}_{2}\right)$, side diameter $\left(\mathrm{x}_{3}\right)$, shell thickness $\left(\mathrm{x}_{4}\right)$, 100-seed weight $\left(\mathrm{x}_{5}\right)$, plumpness $\left(\mathrm{x}_{6}\right)$, kernelrate $\left(\mathrm{x}_{7}\right)$ and empty shell rate $\left(\mathrm{x}_{8}\right)$. And schematic diagram of whole survey procedure is showed in Figure 2.

The experimental data were analyzed by average method and variance analysis, applying mean square error test method by spss17.0 statistical software.

\section{Result and Discussion}

\subsection{Distribution of Hazel Forest}

The results indicate that there are two hazel species in Great Xing'an Ridge region and they respectively are Corylus heterophylla, Corylus mandshuria. The minimum altitude that hazel forest distributes was $312 \mathrm{~m}$ and the highest was $461 \mathrm{~m}$. They mainly grow in mountains or hills from south of Xinlin Town, Huma County, Heilongjian Province to south boundary of Great Xing'an Ridge. Distribution of Corylus Heterophylla was significantly wider than that of Corylus Mandshuria.

Most of Corylus heterophylla grew in the sunny forest edge or shrub south of the hillside. Corylus heterophylla's requirements on soil was very high, so zones where they grew in were fertile, moist, rich in humus and had deep soil. As a result, much area where hazel forest grew had changed into farmland, leading to nearly exhausted resource.

Corylus mandshuri's requirement on sun was not so high that most of them grew in shrub north of the hillside or broad-leaved forest and mixed coniferous forest, and sometimes mixed with Corylus heterophylla. They preferred to soil which were moist, rich in humus, slightly acidic, but tolerates dry, infertile soil. Corylus mandshuria was even found grow in the local limestone rock. However, due to the high requirements on moisture and shade, although their distribution was wide, production turned out to be lower than Corylus heterophylla.

\subsection{Plant Disease and Insect Pest of the Hazel Forest}

Most of hazel forest that distributed in eastern mountains of Heilongjiang Province was under pure wild state with no scientific artificial management, resulting in low yield. Especially for the pest factors, close to $30 \%-40 \%$ of hazel suffered from pests each year, causing enormous 


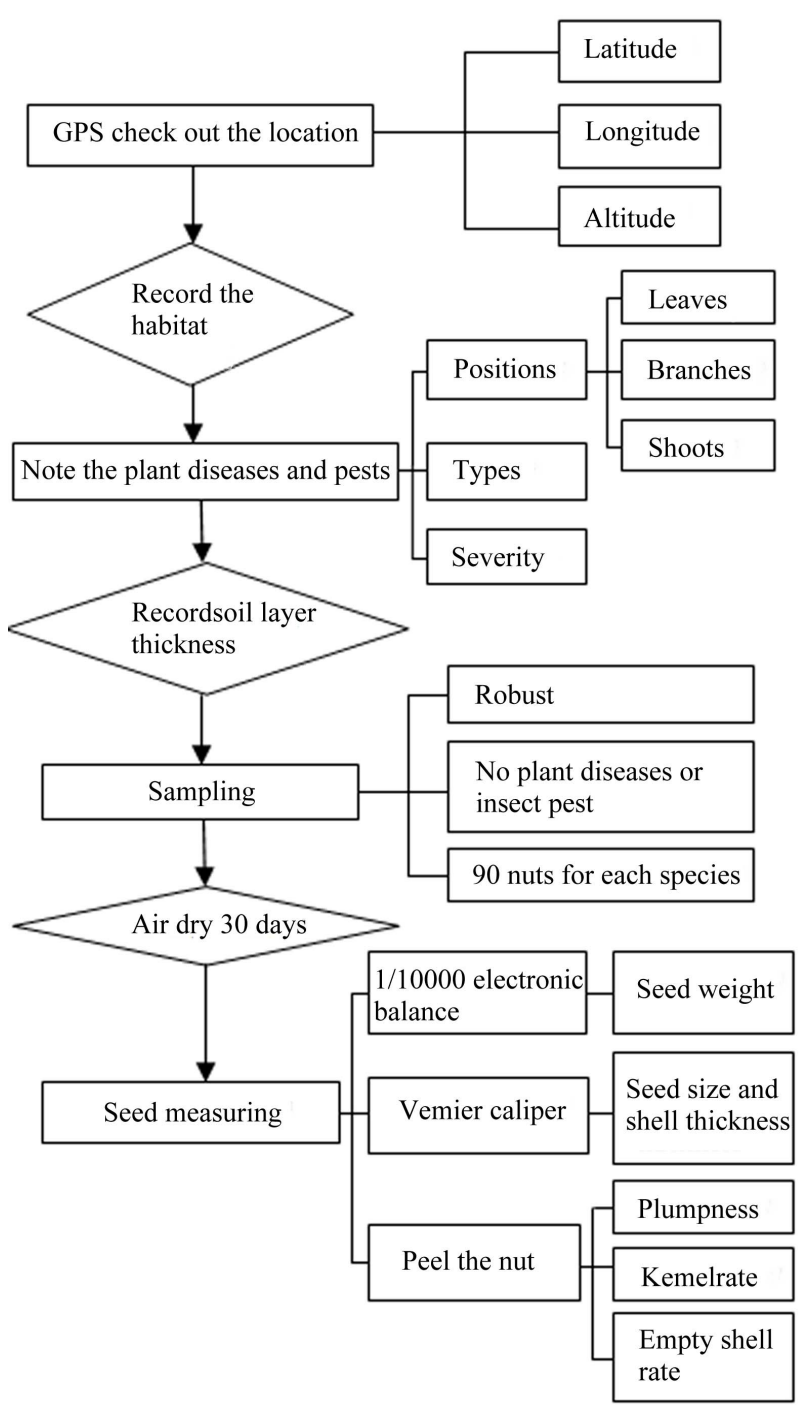

Figure 2. Schematic diagram for survey procedure.

loss [12].

We checked out the main plant disease and insect pest harmful to local wild hazel forest during their growth phase by survey on random samples. The result showed that the main plant disease was powdery mildew, and main insect pest were Curculio dieckmani, Zeuzera sp. Faust Cockchafer, among which Curculio dieckmani turned to be the most harmful.

As for powdery mildew, diseased branches and leaves should be removed in time as soon as diseased plants are found. And for too dense shrub, cutting down the excess branches and thinning could help them improve ventilation, light conditions, which can enhance the tree's resistance to disease. In addition, spraying pesticide from early May to early June is also available for resistance.

As for Faust Cockchafer and the most serious Curculio dieckmani, we can make use of their suspended ani- mation and phototaxis of adult pest to capture them artificially or kill them by black light. What's more, to protect and attract a variety of biological natural enemies can effectively control pests.

\subsection{Soil Layer Thickness of Hazel Forest}

Corylus heterophylla's requirement on soil is very high, so most areas they grow in were fertile, moist sunny hillsides which were rich in humus and had deep soil. The survey showed that thickness of soil layer where Corylus heterophylla grew and hadn't been destroyed proved to be not less than $50 \mathrm{~cm}$; soil at foot of the mountains, beside the highways and those had even been destroyed by farmland can still come up to $40 \mathrm{~cm}$ thick; and no growth signs of Corylus heterophylla was found in those areas thickness of soil layer was less than $30 \mathrm{~cm}$. It indicates that Corylus heterophylla's requirement on soil is not less than $40 \mathrm{~cm}$, so fertile, moist soil rich in humus is necessary for their growth.

Most of Corylus mandshuri grew in shrub north of the hillside or broad-leaved forest and mixed coniferous forest. Soil which was moist, rich in humus, slightly acidic was their most suitable survival place. In addition, they can tolerate dry, infertile soil. Thickness of soil layer where the hazel forest grew and hadn't been destroyed was not less than $45 \mathrm{~cm}$; and most of the soil layer they grow in ranged from $30 \mathrm{~cm}$ to $45 \mathrm{~cm}$. For their strong ability to endure dry, infertile soil, some were truly found in the local limestone rock at $51^{\circ} 20^{\prime} 17^{\prime \prime} \mathrm{N}$ latitude, $124^{\circ} 06^{\prime} 12 " \mathrm{E}$ longitude.

The requirement of hazel on soil is very high, so fertile soil and good drainage is indispensable for high yield. The growth and development will be greatly affected if bred in the heavy clay or sandy soil which is barren, dry or stands too much water. In addition, hazel requires 40 $\mathrm{cm}$ thick soil and some soil should be replaced if they are less than $40 \mathrm{~cm}$ [14]. So, our result quantitatively supports the conclusion that reported by Zhanhui Liu and other experts, which proved that hazel forest need enough fertile soil not less than $40 \mathrm{~cm}$ for normal growth and for development in the process of artificial breeding. This provides a realistic basis for artificial cultivation of hazel resources and lays a theoretical base for improving their yield and quality.

\subsection{Wild Hazel Resource Utilization}

Most of hazel in this area was under the state of natural growth at this stage with no scientific artificial management, combined with destruction from farmland occupation. As a result, production became very unstable. What's more, the strong germination ability of hazel led to too large density of the wood, so ventilation and light became insufficient. Consequently, yield and quality was 
affected seriously, which confirmed the earlier conclusion reported by Minghua Che and other experts. They pointed out that the main natural reasons resulting in low production of hazel were as follows: scarce sunlight for being distributed under the arbores; poor fruiting ability due to too old age; intense competition among individuals because of too large density; arid climate and pest insect [13].

In addition, as local people's value cognition of hazel deepened gradually, greens nuts were always picked by them, resulting in much reduction. Hazel product development was still in primitive stage. There were no processed products, and only primary products were sold on local market.

Hazel has high economic value. To protect and make full use of the wild resource can not only improve its yield and quality, but also safeguard the environment and ensure the sustainable use of wild resources. Given the status of local hazelnut resources, artificial rearing and scientific management are imminent. So, "Artificial and wild hazelnut garden" is necessary on the base of its natural environment, growth and development law. Only to guide it to achieve stable, high yield, and thus the formation of industrial-scale, can it meet the economic development needs of local area.

\subsection{0-Seed Weight Comparison between Corylus heterophylla and Corylus mandshuria}

As we can see in Table 2 that 100-seed weight of Corylus heterophylla was more than twice that of Corylus mandshuria.

\subsection{Nut Size and Shell Thickness Comparison between Corylus heterophylla and Corylus mandshuria}

Traverse diameter, longitudinal diameter, side diameter and shell thickness of 90 Corylus heterophylla nuts and 90 Corylus mandshuria nuts were respectively measured by venier calipers and the result is as followed.

As we can see in Figure 3, traverse diameter and longitudinal diameter of Corylus heterophylla were both significantly higher than that of Corylus mandshuria, respectively higher by $33.07 \%$ and $25.96 \%$. While side diameters of both were not so different for Corylus heterophylla was only $6.67 \%$ higher than Corylus mandshuria in this factor. However, shell thickness of Corylus heterophylla was particularly higher than Corylus mandshu ria by $83.67 \%$, almost twice of it. The results present here show that size of wild Corylus heterophylla was evidently bigger than wild Corylus mandshuria with clearly thicker shell.

What's more, each standard deviation of Corylus hetero-
Table 2. 100-seed weight comparison between Corylus heterophylla and Corylus mandshuria.

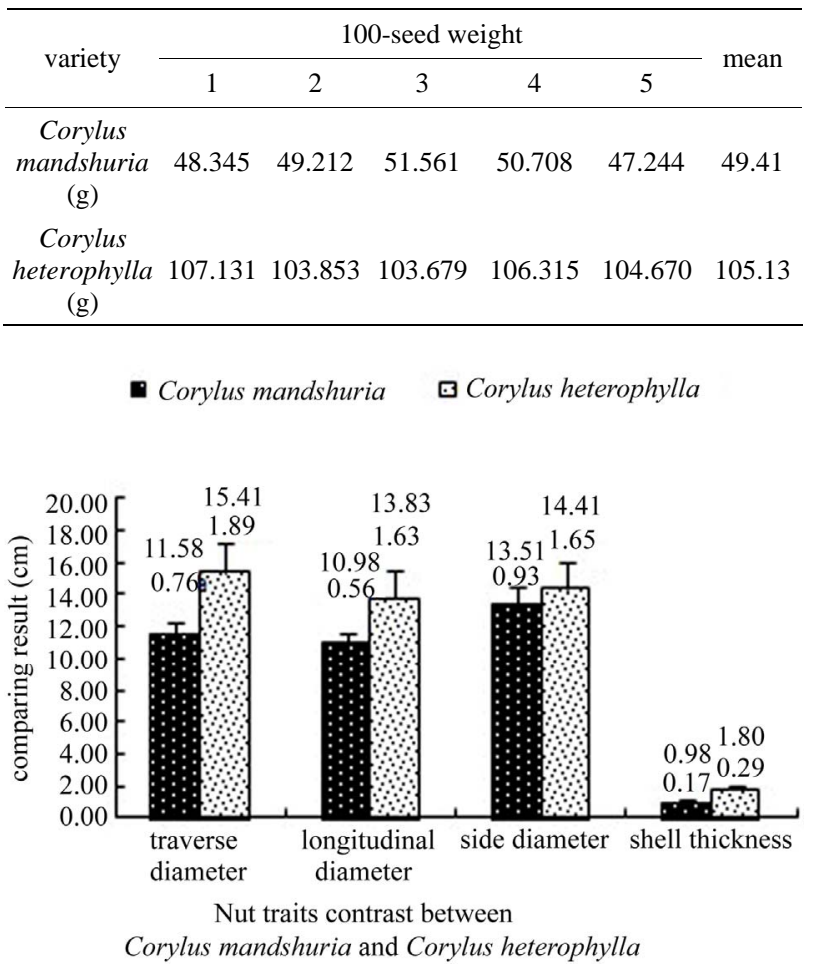

Figure 3. Nut size and shell thickness comparison between Corylus heterophylla and Corylus mandshuria. The data on top of the post were the record of the item; below them were their standard deviation.

phylla nut size was clearly bigger than Corylus mandshuria, which indicates both shape and size of wild Corylus heterophylla were not so homogeneous. However, Corylus mandshuria showed more stable situation in these factors and turned out to be very suitable for commercialization.

\subsection{Plumpness, Kernel Rate and Empty Shell Rate Comparison between Corylus heterophylla and Corylus mandshuria}

Figure 4 showed that plumpness of Corylus mandshuria was significantly higher than that of Corylus heterophylla by $17.51 \%$. Kernel rate of Corylus mandshuria was almost twice of Corylus heterophylla. Empty shell rate of Corylus mandshuria was especially lower than that of Corylus heterophylla, only 1/4 of it. From Figure 3 we can see that size of Corylus mandshuria was clearly smaller than Corylus heterophylla. However, the result present in Figure 4 indicates that Corylus mandshuria was plumper, had much more kernel and much less empty shell than Corylus heterophylla, which showed great value of economic commodity.

That Corylus heterophylla was utilized much more 
Corylus mandshuria $₫$ Corylus heterophylla

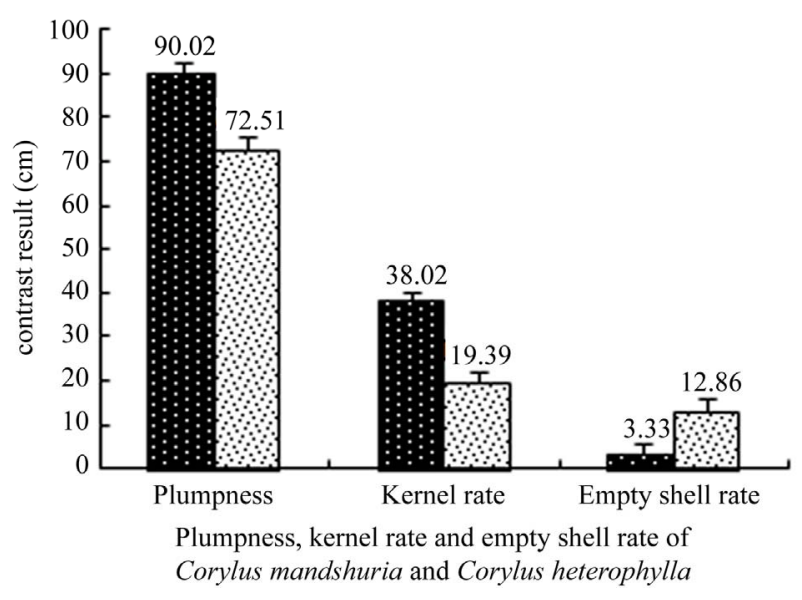

Figure 4. Plumpness, kernel rate and empty shell rate comparison between Corylus heterophylla and Corylus mandshuria.

than Corylus mandshuria was because of its better economic quality traits for it has wide adaptability, large nut yield, easily preserved pollen, high pollination rate and fruiting rate, great variation of cross-breeding offspring and better breeding shape controllability [15]. However, Figure 4 showed that Corylus mandshuria was plumper, had much more kernel and much less empty shell than Corylus heterophylla, and what's more, shell sickness of it turned to be significantly thinner than Corylus heterophylla, all of which showed great cultivation value and and economic commodity value.

That yield of Corylus mandshuria was smaller than Corylus heterophylla was due to its poor distribution. So, it can be predicted that Corylus mandshuria would create significant economic value if cultivated artificially in large-scale.

\section{Acknowledgements}

Wang Qian, Zhao Di and Liu Wanping would like to express profound gratitude to advisor for her painstaking support, encouragement, supervision, and useful suggestions throughout this research. Meanwhile, we appreciate the countless support and help so much from Tang Zhongqiu and Xu Di from Agricultural and Forestry Research Institute of Great Xing'an Ridge.

\section{REFERENCES}

[1] Y. Q. Pan, "Primarily Study on Economic Traits of Large Fruit Hazel and Its Introduction to Changbai Mountains," Quarterly of Forest By-Product and Specialty in China,
Vol. 99, No. 2, 2009, p. 110.

[2] M. Q. Wang, "Determination of Physical Chemical Properties and Fatty Acid Composition of Hazelnut Oil," Vol. 28, No. 8, 2003, pp. 69-70. doi: 1003-7969(2003)08-0069-02

[3] F. Wang and X. S. Zhang, "Wild Plants-Hazelnut Cultivation,” Forestry Survey and Design, Vol. 135, No. 3, 2005, p. 57.

[4] C. Y. Xie and J. Bi, "Hazel," China Soil and Water Conservation, Shaanxi, 1994, pp. 31-32.

[5] Y. B. Zhang and F. Li, "Survey on Wild Hazel ReSources of Changbai Mountain,” Jilin Agricultural Sciences, Vol. 32, No. 5, 2007, pp. 56-57. doi:1003-8701(2007)05-0056-026

[6] Y. H. Zhang, L. Liu and W. J. Liang. "The Fruit Index of China, (Vol. Chestnut, Hazelnut),” China Forestry Press, Beijing, 2005, pp. 193-199.

[7] Z. Y. Long and C. H. Lu, "Resource Distribution and DeVelopment Research Progress of Corylus in Heilongjiang Province," Forest By-Product and Specialty in China, Vol. 77, No. 4, 2005, pp. 41-42.

[8] Z. X. Hou, M. D. Yuan, X. M. Liu and M. P. Zhai, "Survey of Production an Researches on Hazelnut in China," Non-Wood Forest Research, Vol. 26, No. 2, 2008, pp. 123-126. doi:1003-8981(2008)02-0123-04

[9] C. D. Wang, X. Y. Wang and L. C. Zhang, "Growth Characteristics and the Prospect of Researches and Utilizations on Corylus heterophylla," Forestry Survey and Design, Vol. 152, No. 4, 2009. pp. 83-84.

[10] Y. H. Wang, G. Zhang and S. Y. Liu, "Initial Analysis on Development and Utilization of Hazelnut of Da Xing'an Ling,” Modern Agriculture, Vol. 11, 2002, pp. 25-26.

[11] Q. Y. Yu, "Specific Measures for Improving Quality and Yield of Hhazel in Daxing'anling," Quarterly of Forest By-Product and Specialty in China, Vol. 66, No. 3, 2003, p. 18.

[12] L. Liu, Y. M. Ma and W. D. Zhang, "The Hazelnut Pest Survey and Control Measures of Heilongjiang Eastern Mountain,” Forestry Survey and Design, Vol. 146, No. 2, 2008, pp. 66-67.

[13] M. H. Che, X. Yang, S. S. Yang and Y. F. Han, "Situation and Development Strategies of Wild Hazel Resources in Zhalantun City," Modern Argicultural Science and Technology, Vol. 23, 2010, pp. 139,146.

[14] Z. H. Liu, Y. F. Zhou, W. D. Zhang and H. W. Liao, "Cultivation Management Techniques of Hazelnut in Mudan Jiang in the Southern Region,” Forestry Survey and Design, Vol. 153, No. 1, 2010, pp. 106-107.

[15] D. M. Wang and J. L. Zheng, "Breeding Objectives of Hazel and Good Parents Introduction in China," Northern Fruit, Vol. 6, 2008, p. 56. 